INTERNATIONAL BULLETIN

Q F

BACTERIOLOGICAL NOMENCLATURE

A N D

T AXONOMY

Volume 6

July 15,1956

No. 3

Tot onze diepe droefheid overleed heden onze lieve Vader. Behuwden Grootvader

\title{
Albert Jan KLUYVER
}

Hoogleraar aan de Technische Hogeschool

Oud-Voorzitter van de Koninklijke Akademie van Wetenschappen

Ridder in de Orde van de Nederlandse Leeuw

op de leeftijd van 67 jaar.

$\begin{array}{ll}\text { AMSTERDAM } & \text { A. SIEPMAN van den BERG - KLUYVER } \\ & \text { J. J. SIEPMAN van den BERG } \\ \text { LIVERPOOL } & \text { J. C. KLUYVER } \\ \text { s-GRAVENHAGE } & \text { M. SCHIPHORST-KLUYYER } \\ & \text { F. M. M. SCHIPHORST } \\ \text { SALISBURY (Southern Rhodesia) } & \text { C. Th. KLUYVER } \\ & \text { J. W. KLUYVER-van LEUSEN } \\ \text { LEIDEN } & \text { C. A. KLUYYER } \\ & \end{array}$

Delft, 14 Mei 1956.

Nieuwe Laan 3.

Liever geen toespraken.

De verassing is bepaald op Vrijdag $18 \mathrm{Mei}$ a.s. in het Crematorium

te Velsen, na aankomst van trein 12.02 balte Driehuis-Westerveld.

This notice of the passing of Prof. Dr. Albert Jan Kluyver, has saddened the whole fraternity of microbiologists. A review of this life and work in his chosen field will be included in the October, 1956, is sue of this BULLETIN.

(Page 97) 
